\title{
Community-Based Waste Management: Backwater Tourism as a Case Example
}

Emilda K Joseph, ${ }^{\star}$ Tomy K Kallarackal† and Bindi Varghese ${ }^{\ddagger}$

\section{Abstract}

\begin{abstract}
A healthy environment is essential for the growth of Tourism industry. The future of tourism is inevitably related to the environment. As important natural resources, backwaters should be preserved in a sustainable manner. SWM emerged as an essential for keeping tourist destination clean and livable. This paper analyses the community-based waste management process in one of the famous backwater tourist destinations of Kerala and explains the roles and activities of all stakeholders and their relationship at the community level. This paper also helps to identify the reasons for CBWM and justify its need for community participation. It is based on semi-structured interviews and direct observation conducted on the research area.Regardless of efforts to improve community involvement in waste management there is a lack of comprehension and understanding in the participation of community level stakeholders.
\end{abstract}

Keywords: Community-based waste management, Sustainable Tourism, Solid waste management, Backwater Tourism, Community Participation.

${ }^{*}$ Christ College, MG University, Kerala, India; email

† Christ University, Bengaluru, India; tomy.kk@christuniversity.in

‡ Christ University, Bengaluru, India; bindi.varghese@christuniversity.in 


\section{Introduction}

A healthy environment is essential for the growth of Tourism industry. The future of tourism is inevitably related to the environment. As important natural resources, backwaters should be preserved in a sustainable manner. From an environmental perspective, solid waste management is an important feature of environmental management of institutions' (I, Pirani, \& Arafat, 2014)and it is a practical discipline examining solution for individual waste problems connected with tourism sector (Pongracz, 2002). The improper solid waste management can lead to environmental, economic and social impacts (Ezeah, C., Fazakerley, J. and Byrne, T. 2015).

In adequate waste management and sanitation has a consequence on the health and well-being of communities and local environment. (ICM, 2005)Therefore Planning and implementing a comprehensive program for waste management can prevent or eradicate the waste problems of any tourism destinations (United States Environmental Protection Agency, 2002). Miss management of solid waste also had knock-on effects on the economies of the area including devaluation of property loss of investments in tourism and erosion of job opportunities from tourism. (ICM, 2005)

To address these common problems it is essential to get the community leaders and other stakeholders involved at the beginning of the waste management process. (ICM, 2005). The core group member for solid waste management includes all stakeholders' public, private and nongovernmental organization. The general approach to solid waste management includes social preparation, stakeholders' identification, Social mobilization, community organizing, development, monitoring, and evaluation. (Mendoza, 2001). And this can be considered as best practice in managing wastes (Tallei, Iskandar, Runtuwene, \& Filho, 2013).

Community awareness can be improved through various seminars, technical research, databases and social outreach programs which aimed at those who influence public opinion. (United States Environmental Protection Agency,2002). The inception workshops where in the roles and responsibilities of the team were discussed will provide an opportunity to all stakeholders to participate in 
theplanning process. (ICM, 2005). A ladder approach can be used for starting off with basic information on waste management related social, human, environmental issues and then moving to concepts and approaches to waste management. (ICM, 2005). According to Nair \&Jayakumar(2008),Zero waste is an ideal goal for management of discard in the long run of waste management problems accepted by many communities and countries.

The major problem of waste management is many communities and destinations still follow the old paradigm of waste management. That is collect, transport and disposes of. So efforts are needed to transform this old community's paradigm into a new environmental paradigm (Tallei, Iskandar, Runtuwene, \& Filho, 2013). A key strategy in waste management is to get stakeholders involved by engaging them in community activities. (ICM, 2005).

There are many reasons why community-based waste management is important. It will help thelocal community to generated income, provide employment opportunities, improve cleanliness, minimized the dumping of waste, improve discipline among households, improved cooperation among households, and reduced the volume of the cost. (Cabrido, 2006).

Community based ecological solid waste management programme can be improved through training, campaign, provide simplifies guidelines, clearly defined roles and responsibilities, educate local community, coordination between various stakeholders, training assistance, evaluation or monitoring, involvement of school and schoolchildren. (Cabrido, 2006).

Community-based participatory research can be implemented to create the public awareness in the waste disposal management and encourage the community to solve the problem themselves. (Noosorn, Kanokthet, \& Manoton, 2011). In order to analyze the origin and consequences of the problems, such understanding will enable the community to be deeply aware of the facts of thesituation and social behavior that caused waste management problems. (Noosorn, Kanokthet, \& Manoton, 2011). 


\section{Case Study Area}

Backwater is 'a part of a river not reached by the current, where the water is stagnant', ora body of water (as an inlet) that is out of the main current of a larger body, and Kerala showcases a lot of its charming backwaters. The backwaters of Kerala flow through four major districts of Kerala viz., Kollam, Alappuzha, Kottayam, and Kochi. The largest backwater body of Kerala, the Vembanadu Lake runs through Alappuzha and Kottayam districts and opens out into the sea at the Kochi port. Backwaters of Kerala take every visitor to the most enchanting experience of Kayals (lakes), Kettuvallams, (house boats) and countless lagoons. A journey along streams and water ways allows every tourist to take pleasure of unique life. Tourists can refresh themselves with natural best tender coconut which is found richly along the banks of Vembanadu Lake. This amazing backwater is also blessed with charming natural rich islands. Snake boat race, local cuisine of steamed tapioca and unique preparation of Karimeen(Green Chromide or Pearl spot fish), unique classical dance forms and art forms of Kerala like Kathakali, Kuchipudi, Mohiniyattam, Bharathanatyametc., bring afeast for eyes to every visitor.

\section{The purpose of the research}

This paper analyses the community-based waste management process in the famous backwater tourist destinations of Kerala and explains the roles and activities of all stakeholders and their relationship at the community level. This paper also helps to identify the reasons for CBWM and justify its need for community participation 


\section{Materials and Methods}

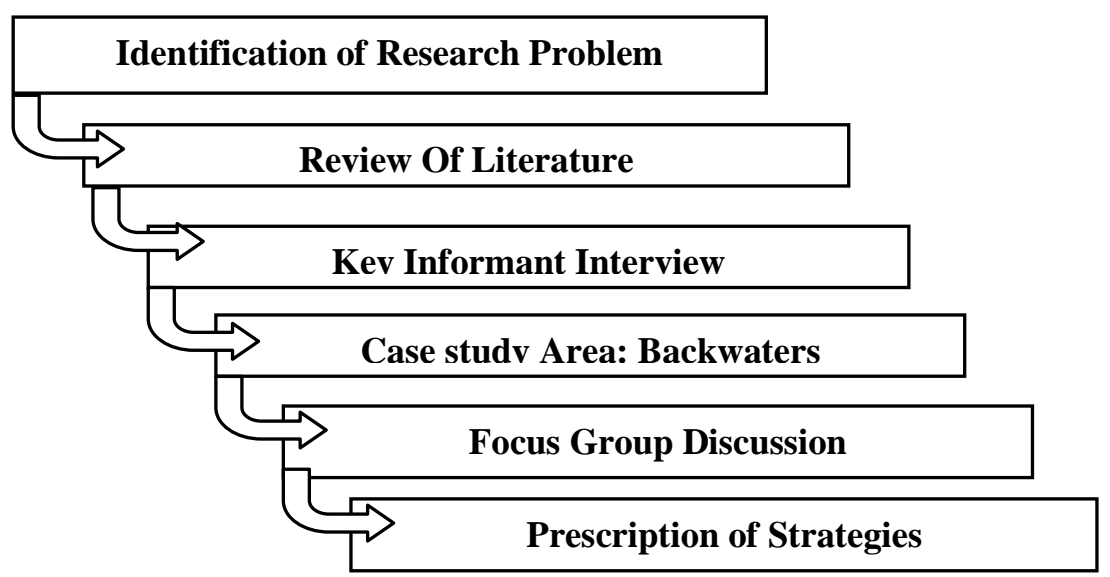

Fig 1 Applied Methodology

This research emphasis on qualitative research methods to provide a rich description of the experience of the case study; a combination of following data collection methods is used to obtain information about stakeholders and their attributes: project documents, informal andsemi-structured interviews and direct observation method

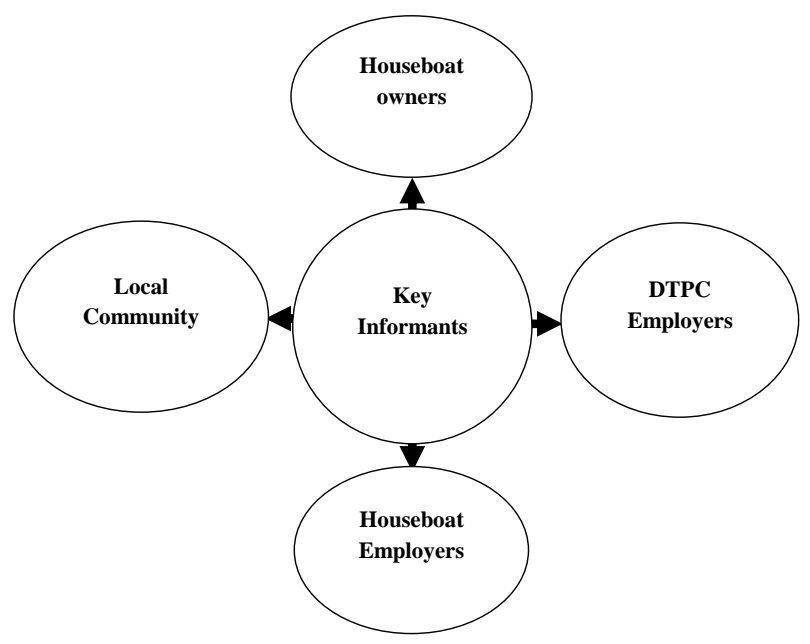

Fig 2 Key Informants of the study 
Key informants comprising with the houseboats employees, houseboat owners, local community representatives and DTPC employees were interviewed

The identification and inclusion of stakeholders are critical aspects of the implementation of community-based waste management. A number of key stakeholders are listed in Figure 2 Houseboat owners, Houseboat employers, DTPC employees and Local community. These stakeholders have different roles in relation to waste management. The challenge of community-based waste management is to get them agree to work together for a removal of waste from the backwater. Also, the backwater community shares a common social and geographic context.

\section{Current waste management practices in the Backwater Region}

Environmental management: From an environmental perspective solid waste management is an important feature of environmental management of institutions' (I, Pirani, \& Arafat, 2014). However, it is predominantly the larger group of Houseboat owners which have been fulfilling environmental management practices. Smaller properties do not always have the financial means or administrative structure to make it possible. Many houseboat owners are less concerned about carrying out environmental management in general and waste management in particular. This is because smaller properties believe that they are generating small quantities of waste.

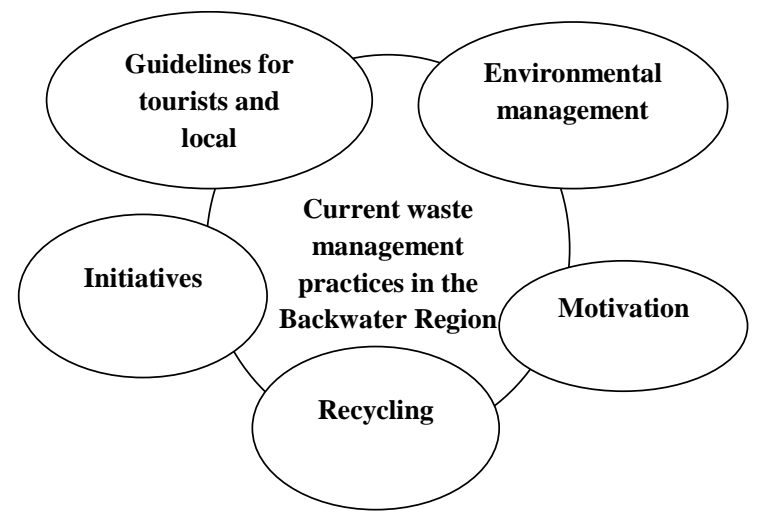

Fig 3 Challenges facing waste management in Backwater Region 
Motivation: There is no proper motivation from managers or houseboat owners to implement eco-friendly practices. This lack of motivation arises due to many issues such as houseboat owners feeling that the waste quantities their properties generate are not significant enough to make viable their spending of time and money on practices such as sorting and recycling and feeling that it was more the responsibility of larger properties to implement environmental management practices.

Recycling: It is very challenging to entire houseboat employees to embrace following recycling tactics a) segregating the waste b)subcontracting waste operations in order to separate food waste c) storage of waste d) transportation and logistical problem; e)health and sanitation problem, f) unaware of recycling process etc

Initiatives:The interaction with Government officials reveals that the government is focusing on the execution of practical guidelines for sustainable tourism by giving special thrust to backwater tourism activities. Government officials are of the opinion that if they get active supports from local communities, the promotion of sustainable tourism in the backwater regions would be much easier. Many schemes implemented like Sewage Treatment Plant Kumarakom, Pipeline composting and Biogas plants to extract the tourism potential of backwaters through sustainable tourism. New project on the sewage treatment plant aims at collecting waste materials from the houseboats by going directly to it.

Guidelines for tourists and local community: There is no proper guideline for tourists in houseboats. Educate and train the local community and the general public on waste management, i.e., segregation of waste at source into biodegradable (wet) waste and non-biodegradable (dry) waste. Proper instructions should be given to tourists through the concerned authorities for waste disposal.

\section{Findings}

Backwater face some issues in expanding CBWM, in particular, there is no consideration for the participation of community level stakeholders at the beginning of the planning process, implanting process and the evaluation process. 
There are only a few linkages between the tourism industry and other sectors to solve wastemanagement problems in the backwater. Because of this shortage of relation and little coordination between various stakeholders, solid waste management issue still continues in the backwater region. Usually, a formal linkage only exists between responsible tourism initiatives and tourism activities. Because of this shortage of relations, there is little coordination between the various stakeholders involved in solid waste management.It is further compounded by the absence of platforms and forums for discussing and solving waste management issues in the backwater within the tourism department level for the participation of all stakeholders.

In overall, the current waste management in study area does not consider stakeholders participation seriously.

\section{Conclusion}

Stakeholder roles and relationship among them for solid waste management in community level is a crucial aspect. DTPC should take the mainrole related to waste management at tourism level and provide anopportunity for participation of other stakeholders. Relations among tourism stakeholders need to improve the planning, implementing and evaluation of solid waste management.Stakeholders awareness raising, mobilization, and sensitization in solid waste management are the leading features which could improve Community waste solid management. Adding a process of designation for CBWM at tourism level is recommended.

\section{Reference}

Agency., U. S. (2002). Solid Waste Management: A Local Challenge with Global Impacts. U.S.A.

Anschütz, J. (1996, May). Community-based solid waste management and water supply projects problems and solutions compared A survey of the literature. Retrieved from Urban Waste Expertise Programme Community Participation in Waste Management: http://www.waste.nl 
Cabrido, C. A. (2006). Community Based Ecological solidwaste Management Programme in the Philippines. Barangay: UNDP.

Ezeah, C., Fazakerley, J., \& Byrne, T. (2015). Tourism Waste Management in the European Union: Lessons Learned from Four Popular EU Tourist Destinations. American Journal of Climate Change, 431-445.

Gotame, M. (2012). Community Participation In Solid waste management Kathmandu. Norway: University of Bergen.

ICM, S. (2005). Improving Sanitation through Community Based waste management: Experience in Cambodia and Lao PDR. Cambodia: UNDP,World Bank Group, PEMSEA.

I, S., Pirani, \& Arafat, H. A. (2014). Solid waste management in the hospitality industry: A Review. Journal of Environmental Management: Elsevier, 320-336.

Kariminia, S., Ahmad, S. S., \& Hashimb, R. (2012). Assessment of Antarctic Tourism Waste Disposal and Management Strategies towards a Sustainable Ecosystem. Elsevier, 723-734.

Mendoza,G. O. (2001). Community-based Solid Waste Management Project in Sitio San Nicolas. Sitio San Nicolas.

Mongkolnchaiarunya, J. (2005). Promoting a community-based solidwastemanagement initiative in local government:Yala municipality, Thailand. Pergamon, 27-40.

Nair, S. K., \& Jayakumar, C. (2008). A Handbook on Waste Mangement in Rural Areas- A Zero Waste Approach. Thiruvananthapuram: UND-India.

Noosorn, N., Kanokthet, T., \& Manoton, A. (2011). Communitybased participatory on waste disposal management research in Yom's Riverside community. Journal of Public Health and Development, 301-311.

Pongrácz, E., Phillips, P. S., \& Keiski, R. L. (2004). Evolving the Theory of Waste Management-Implications to waste minimization. Waste Minimization and Resources Use Optimization Conference. (pp. 61-67). University of Oulu, Finland: Oulu University Press.

Radwan, H. R. (2010). Managing solid waste in small hotels. Journal of Sustainable Tourism, 175-190.

Rämet, J., Tolvanen, A., Kinnunen, I., Törn, A., Orell, M., \& Siikamäki, P. (2005). Sustainable use of renewable natural 
resources - from principles to practices. Helsinki: University of Helsinki Department of Forest Ecology Publications.

Richards, G., \& Hall, D. (2002). Tourism and Sustainable Community development. London: Routledge.

Tallei, T. E., Iskandar, J., Runtuwene, S., \& Filho, W. L. (2013). Local Community-based Initiatives of Waste Management Activities on Bunaken Island in North Sulawesi, Indonesia. Research Journal of Environmental and Earth Sciences, 737743. 